\title{
Influence of Different Nutrient Management Practices on the Performance of Rice (Oryza sativa L.) Variety CAU R1 under Different Moisture Regimes
}

\author{
Barnali Narayan $^{1}$, L. Nabachandra Singh ${ }^{1}$, K. Nandini Devi ${ }^{1}$, \\ S. Jekendra Singh ${ }^{2}$ and N. Gopimohan Singh $^{3}$ \\ ${ }^{1}$ Department of Agronomy, ${ }^{2}$ Department of Soil Science and Agricultural Chemistry, \\ ${ }^{3}$ Department of Agricultural Statistics, College of Agriculture, Central Agricultural \\ University, Imphal, Manipur-795004, India
}

*Corresponding author

\section{A B S T R A C T}

K e y w o r d s
Integrated nutrient
management,
Moisture levels,
FYM, Azolla,
Continuous
flooding, Panicle
Initiation, No. of
tiller, Panicle
length, Grain yield,
Straw yield, WUE
Article Info
Accepted:
18 August 2020
Available Online:
10 September 2020

A pot experiment was conducted at College of Agriculture, Central Agricultural University, Imphal during Kharif 2019 to study the influence of different nutrient management practices on the performance of rice (Oryza sativa L.) variety CAU R1 under different moisture regimes in FRBD (with 3 replications) with three Nutrient Management Practices viz. recommended dose of $\mathrm{N}$ as fertilizer $\left(60 \mathrm{~kg} \mathrm{~N} / \mathrm{ha}\right.$ from Urea) $\left(\mathrm{N}_{1}\right)$, Integrated Nutrient Management I (40 kg N/ha from Urea $+20 \mathrm{~kg} \mathrm{~N} /$ ha from FYM) $\left(\mathrm{N}_{2}\right)$, Integrated Nutrient Management II (30 kg N/ha from Urea $+15 \mathrm{~kg} \mathrm{~N} / \mathrm{ha}$ from FYM $+15 \mathrm{~kg} \mathrm{~N} / \mathrm{ha}$ from Azolla) $\left(\mathrm{N}_{3}\right)$ and three Moisture regimes viz. continuous Flooding $(5 \mathrm{~cm}$ depth $)\left(\mathrm{M}_{1}\right)$, No standing water (wetting soil just after hairy cracks appear) $\left(\mathrm{M}_{2}\right)$ and Maintaining $5 \mathrm{~cm}$ water depth only at tillering, Panicle Initiation (PI) and flowering stage $\left(\mathrm{M}_{3}\right)$ replicated thrice. Analysed data revealed that among the different nutrient management practices, $\mathrm{N}_{3}$ treatment level which is the integrated nutrient management approach showed excellent significant result along with $\mathrm{M}_{3}$ level of Moisture regime on the performance viz. biometric parameters (no. of tiller, total leaf no., panicle length etc.) and yield \& yield parameters (effective tillers no., grain and straw yield etc.) and WUE of rice crop and for both sustainable production and higher yield.

\section{Introduction}

Rice (Oryza sativa L.) is one of the most important crops in the world, growing in over 156 million hectares of land having overall worldwide production (paddy rice) of 650 million tons per annum. Now, rice is being grown in 117 countries and is a staple food for many countries. India is considered as one of the centre of origin of rice (Oryza sativa spp. indica) and an important centre of its diversity (Ramaiah, 1953) and it alone produces nearly one fourth $(21 \%)$ of the rice in the world, next only to China (FAO, 2009). Rice is the staple food for its large population and this crop is cultivated in almost all the Indian states under a remarkably wide range of agro-climatic conditions and ecological 
situations. It is also the staple food of Manipur, country's one of the north-eastern states. Due to reduction in the productivity, in the recent past it was unable to meet the burgeoning demand for rice which was much higher than its supply capacity (Singha, 2013). For instances, the shortage of rice in 2009-10 was around 116 thousand tonnes in the state.

To keep up with population growth and income-induced demand for food in the most Asian countries, rice production needs to increase in coming decades. India has to produce 114 million tons of rice by the year 2030 to meet the requirement of food grain of its burgeoning population.

Exploiting the production potential of rice varieties through good agronomic management is one of the alternatives to safeguard and sustain food security in India, especially by nutrient and water management, the two most important aspects regarding production. Chemical fertilizers have contributed substantially to the spectacular increase in its yield. However, growing crop with indiscriminate use of fertilizers has resulted into degradation of lands owing to low yields with poor quality of produce. Swaminathan (2002) opined that the 'green revolution' had gradually turned into a 'greedy revolution' as evident in the indiscriminate use of inorganic inputs to attain higher productivity. The decline or stagnation in yield has been attributed to nutrient mining and reduced use of organics (John et al., 2001).

On the other hand, continuous application of organic fertilizer alone on rice field resulting low yield and low $\mathrm{N}$ and $\mathrm{K}$ content at the mid tillering stage of rice plant (Javier et al., 2004) and can't meet the burgeoning food demand. Therefore, integrated use of organic manures and inorganic fertilizers has assumed great importance for sustainable production and maintaining soil health (Singh et al., 2005). Organic manure and inorganic not only supplies macro and micro nutrient, it also improves the soil properties, improve the uptake of nutrients and help in better crop growth which will ultimately results in higher productivity. Probably, there will be no universally best integrated nutrient management practice. Thus more efforts are needed to identify the improved nutrient management strategy for a particular target environment.

Rice is a major consumer of irrigation water. It consumes about $80 \%$ of the total irrigated fresh water resources. In Asia, irrigated agriculture uses $80-90 \%$ of the fresh water and about $50 \%$ of that is used in rice farming (IRRI, 2001). Fresh water, however, is becoming increasingly scarce because of population growth, increasing urban and industrial development and the decreasing availability resulting from pollution and resource depletion (Belder et al., 2004). Decreasing water availability for agriculture threatens the productivity of irrigated rice ecosystem. Though there are innovative methods such as sprinkler irrigation, drip irrigation available to increase the irrigation efficiency, they are not suitable for a crop like rice which demands standing water for its growth. So, it is important to cut down water supply for rice cultivation but without effecting rice yield.

\section{Materials and Methods}

\section{Experimental site}

The pot experiment was conducted in polyhouse of the College of Agriculture, Central Agricultural University, Imphal campus, during the kharif 2019. The geographical position of the polyhouse is as such - Latitude $24^{0} 45^{\prime} \mathrm{N}$, Longitude $93^{0} 54^{\prime} \mathrm{E}$ 
with an Altitude of $774 \mathrm{~m}$ above mean sea level. The soil used for the experiment was local soil of clay loam in texture with initial medium level available $\mathrm{N}(321.21 \mathrm{~kg} / \mathrm{ha}), \mathrm{P}$ $(22.97 \mathrm{~kg} / \mathrm{ha})$ and $\mathrm{K}(279.7 \mathrm{~kg} / \mathrm{ha})$ content respectively. The $\mathrm{pH}$ and Organic Carbon content was 5.6 (acidic) and 1.12\% (high) respectively. The location of experiment falls under subtropical humid climatic type with a maximum and minimum monthly temperature as in the range of $26.3-30.7^{\circ} \mathrm{C}$ and 13.5 $22.5^{\circ} \mathrm{C}$ and with mean monthly rainfall of $4.7 \mathrm{~mm}$ during the study time. The experiment was laid out in Factorial Randomized Block Design (FRBD) and replicated thrice. So, total numbers of pots required were 27 (9x3) and they were laid out accordingly.

\section{Treatment details}

There were basically two major factors i.e. Nutrient management practices and different Moisture regimes with each having 3 levels. The levels for different nutrient management practices are $\mathbf{N}_{\mathbf{1}}$ : RDF viz. @ $60 \mathrm{~kg} \mathrm{~N} / \mathrm{ha}$ from Urea, $\mathbf{N}_{2}$ : Integrated Nutrient Management I viz. $40 \mathrm{~kg} \mathrm{~N} / \mathrm{ha}$ from Urea $+20 \mathrm{~kg} \mathrm{~N} / \mathrm{ha}$ from FYM, and $\mathbf{N}_{\mathbf{3}}$ : Integrated Nutrient Management II viz. $30 \mathrm{~kg}$ N/ha from Urea + $15 \mathrm{~kg} \mathrm{~N} / \mathrm{ha}$ from $\mathrm{FYM}+15 \mathrm{~kg} \mathrm{~N} / \mathrm{ha}$ from Azolla. A constant dose of $40 \mathrm{~kg} \mathrm{P}_{2} \mathrm{O}_{5}$ and 30 $\mathrm{kg} \mathrm{K}_{2} \mathrm{O} / \mathrm{ha}$ in the form of SSP and MOP were applied along with each treatment level respectively. In case of different moisture regimes, the levels are $\mathrm{M}_{1}$ : Continuous Flooding (up to $5 \mathrm{~cm}$ depth), $\mathrm{M}_{2}$ : No standing water (wetting soil just after hairy cracks appear) and $\mathrm{M}_{3}$ : Maintaining $5 \mathrm{~cm}$ water depth only at tillering, Panicle Initiation (PI) and flowering stage. So, total $9\left(3^{2}\right)$ treatment combinations were there expressed in Table 1.

\section{Cultural practices}

There were total 27 numbers of plastic pots, each with a size of $24 \mathrm{~cm} \times 24 \mathrm{~cm} \times 30 \mathrm{~cm}$.
Each pot contained with $10 \mathrm{~kg}$ of soil which was collected from local field. The organic portion of nutrient levels viz. FYM and Azolla were mixed with soil in their proportionate quantity at 15-20 days prior to transplanting. The inorganic portions were applied at the time of transplanting. At transplanting time, each pot was watered and a $5 \mathrm{~cm}$ water level was maintained and 3 individual seedlings of 25 days old were transplanted separately in each pot. After that, the different treatment levels were followed in their respective manner and timings.

\section{Observation recorded}

In this case observation related to growth parameters or biometric observations (plant height, number of tillers/hill, leaf number) were taken at 20 days interval from transplanting (on 28 July, 2019) up to harvest (on 17 November, 2019). The different parameters related to yield attributes that were taken into consideration are effective tillers number/ hill, panicle length, number of spikelets/panicle, test weight. And the considered yield parameters were grain yield, straw yield and harvest index. One more important parameter, water use efficiency of rice was also considered.

\section{Results and Discussion}

\section{Biometric observation}

Significant influence of different nutrient management practices on plant height, number of tillers/hill and leaf number was found at different growth stages viz. 40, 60, 80,100 DAT and at harvest. $\mathrm{N}_{1}(60 \mathrm{~kg} \mathrm{~N} / \mathrm{ha}$ from Urea) had significantly higher plant height at around 40 and 60 DAT than other treatment practices. This is might be due to the fact that the inorganic fertilization has quick, adequate and easy nutrient supplying capacity to the crop. Similar findings are 
obtained from the findings of Kumar et al., (2014). However, on later stages it was at par with $\mathrm{N}_{3}$.

$\mathrm{N}_{3}$ recorded with significantly maximum number of tillers per hill from 40 DAT to at Harvest time. Inorganic fertilization along with organic supplements can supply adequate nutrient and maintain proper soil physical condition for crop growth which might be the reason that it played a significant role in increasing the number of tillers per hill. This result proves the findings of Jeyajothi and Durairaj (2015).

$\mathrm{N}_{3}$ level exhibited significantly more number of leaves specifically at 40, 60 and 80 DAT. The reason might be the fact that recommended fertilizer along with organic manuring might have supplied adequate quantity of nutrients as per as crops requirement rapidly. Additionally it had enhanced the dry matter production of the crop like total number of leaves. The result is in supported with Oo_et al., (2010) reports.

The effect of different moisture levels onplant height and number of tillers per hill was significant. Significantly taller plants were recorded under treatment $\mathrm{M}_{1}$ (Continuous Flooding) which did not differ significantly with $\mathrm{M}_{2}$ (No standing water). The magnitude of increase in plant height was maximum between 20 to 40 DAT. The favourable growing and nutrient supply environment might have resulted in higher dry matter production leads to more plant height in continuous flooding. This is in supporting of the findings of Pandey et al., (2010). For tillers no./hill, significant effect was there with maximum number of tillers per hill was associated with $\mathrm{M}_{3}$ at later stages viz. 80, 100 DAT and at harvest. Alternate wetting and drying irrigation with maintaining flooding at critical stages of crop growth might have created favourable situation of crop growth led to enhanced tillers number per plant characteristics. This result can be supported by the reports of IRRI, 2009 and Bouman et al., (2007).

Effect of different moisture levels on leaf number of rice at different growth stages viz. 40, 60, 80, 100 DAT and at harvest was found to be non-significant (Table 2-7).

\section{Effective tillers/hill}

Different nutrient management practices had significant influence on effective tillers number per hill. $\mathrm{N}_{3}$ level had maximum significant effective tillers per hill than any other levels. Adequate fertilization along with added advantages of FYM and Azolla might have beneficial effect on yield attributes like effective tillers per hill. Similar results have been reported by Singh et al., (2013).

Different moisture levels had significant influence on effective tillers number per hill and highest significant effective tillers number was found for $\mathrm{M}_{3}$ level which though was statistically at par with $\mathbf{M}_{1}$. Following a safe version of alternate wetting and drying irrigation with maintaining flooding at critical stages of crop growth might have created favourable situation of crop growth led to enhanced yield attributing characters just like the continuous flooding environment, with saving of irrigation water and no decline of rice yield. This result is in close proximity to the reports of IRRI, 2009 and Bouman et al., (2007).

\section{Panicle length $(\mathrm{cm})$}

Different nutrient management practices as well as different levels of moisture did not have any significant effect on length of panicle. However highest length was associated with $\mathrm{N}_{1}$ level and $\mathrm{M}_{1}$ level respectively. 


\section{Number of spikelets/panicle}

The effect of different nutrient management practices on spikelets number per panicle had not been significant. However highest case associated with $\mathrm{N}_{2}$ level.

Significant influence of different levels of moisture on number of spikelets per panicle was found with level $M_{1}$ having highest significant spikelets number which is statistically at par with $\mathrm{M}_{2}$ (No standing water) level of moisture. Frequent irrigation might have enabled the crop plants to grow lavishly by providing favourable microclimate and increase absorption, translocation, assimilation of nutrients by plants for various physiological processes which led to enhance yield attributing characters. Similar results were observed with
Lu et al., (2000) and Pandey et al., (2010).

Test weight (g)

The effect due to different nutrient management practices on test weight of rice was found to be significant. It was noticed that $\mathrm{N}_{3}(30 \mathrm{~kg} \mathrm{~N} / \mathrm{ha}$ from Urea $+15 \mathrm{~kg} \mathrm{~N} / \mathrm{ha}$ from FYM $+15 \mathrm{~kg} \mathrm{~N} / \mathrm{ha}$ from Azolla) had the significantly higher test weight value than any others. Inorganic fertilization along with organic sources like FYM and Azolla increases the efficiency of applied nutrients and can enhance the growth and yield attributes of the crop. Similar findings been reported from Dwivedi et al., (2012).

The effect of different moisture levels on test weight of rice had been found to be nonsignificant.

\section{Table.1 Different treatment combinations}

\begin{tabular}{|c|c|}
\hline$T_{1}\left(N_{1} M_{1}\right)$ & @ 60 kg N/ha from Urea + Continuous Flooding (5 cm depth). \\
\hline $\mathbf{T}_{2}\left(\mathbf{N}_{1} \mathbf{M}_{2}\right)$ & $\begin{array}{l}\text { @ } 60 \mathrm{~kg} \mathrm{~N} / \mathrm{ha} \text { from Urea + No standing water (wetting soil just after } \\
\text { hairy cracks appear). }\end{array}$ \\
\hline $\mathbf{T}_{\mathbf{3}}\left(\mathbf{N}_{\mathbf{1}} \mathbf{M}_{\mathbf{3}}\right)$ & $\begin{array}{l}\text { @ } 60 \mathrm{~kg} \mathrm{~N} / \mathrm{ha} \text { from Urea + Maintaining } 5 \mathrm{~cm} \text { water depth only at } \\
\text { tillering, Panicle Initiation (PI) and flowering stage. }\end{array}$ \\
\hline $\mathbf{T}_{4}\left(\mathbf{N}_{2} \mathbf{M}_{1}\right)$ & $\begin{array}{c}\text { @ } 40 \mathrm{~kg} \mathrm{~N} / \mathrm{ha} \text { from Urea }+20 \mathrm{~kg} \mathrm{~N} / \mathrm{ha} \text { from FYM + Continuous } \\
\text { Flooding (5 cm depth). }\end{array}$ \\
\hline $\mathbf{T}_{5}\left(\mathbf{N}_{2} \mathbf{M}_{2}\right)$ & $\begin{array}{l}\text { @ } 40 \mathrm{~kg} \text { N/ha from Urea }+20 \mathrm{~kg} \mathrm{~N} / \mathrm{ha} \text { from FYM + No standing } \\
\text { water (wetting soil just after hairy cracks appear). }\end{array}$ \\
\hline $\mathbf{T}_{6}\left(\mathbf{N}_{2} \mathbf{M}_{3}\right)$ & $\begin{array}{c}\text { @ } 40 \mathrm{~kg} \text { N/ha from Urea }+20 \mathrm{~kg} \text { N/ha from FYM + Maintaining } 5 \mathrm{~cm} \\
\text { water depth only at tillering, Panicle Initiation (PI) and flowering } \\
\text { stage. }\end{array}$ \\
\hline $\mathbf{T}_{7}\left(\mathbf{N}_{3} \mathbf{M}_{1}\right)$ & $\begin{array}{c}\text { @ } 30 \mathrm{~kg} \mathrm{~N} / \mathrm{ha} \mathrm{from} \mathrm{Urea}+15 \mathrm{~kg} \text { N/ha from FYM }+15 \mathrm{~kg} \mathrm{~N} / \mathrm{ha} \text { from } \\
\text { Azolla+ Continuous Flooding }(5 \mathrm{~cm} \text { depth). }\end{array}$ \\
\hline $\mathbf{T}_{8}\left(\mathbf{N}_{3} \mathbf{M}_{2}\right)$ & $\begin{array}{c}\text { @ } 30 \mathrm{~kg} \mathrm{~N} / \mathrm{ha} \text { from Urea }+15 \mathrm{~kg} \mathrm{~N} / \mathrm{ha} \text { from FYM }+15 \mathrm{~kg} \mathrm{~N} / \mathrm{ha} \text { from } \\
\text { Azolla+ No standing water (wetting soil just after hairy cracks } \\
\text { appear). }\end{array}$ \\
\hline $\mathbf{T}_{9}\left(\mathbf{N}_{3} \mathbf{M}_{3}\right)$ & $\begin{array}{c}\text { @ } 30 \mathrm{~kg} \mathrm{~N} / \mathrm{ha} \text { from Urea }+15 \mathrm{~kg} \text { N/ha from FYM }+15 \mathrm{~kg} \mathrm{~N} / \mathrm{ha} \text { from } \\
\text { Azolla+ Maintaining } 5 \mathrm{~cm} \text { water depth only at tillering, Panicle } \\
\text { Initiation (PI) and flowering stage. }\end{array}$ \\
\hline
\end{tabular}


Table.2 Periodic plant height $(\mathrm{cm})$ of rice as affected by different nutrient management practices and different levels of moisture

\begin{tabular}{|c|c|c|c|c|c|c|}
\hline Treatments & $\begin{array}{l}20 \\
\text { DAT }\end{array}$ & $\begin{array}{l}40 \\
\text { DAT }\end{array}$ & $\begin{array}{l}\text { 60 } \\
\text { DAT }\end{array}$ & $\begin{array}{l}80 \\
\text { DAT }\end{array}$ & $\begin{array}{l}\text { 100 } \\
\text { DAT }\end{array}$ & $\begin{array}{l}\text { At } \\
\text { harvest }\end{array}$ \\
\hline \multicolumn{7}{|l|}{ Nutrient management practices } \\
\hline Recommended dose of $\mathbf{N}\left(\mathbf{N}_{\mathbf{1}}\right)$ & 59.63 & 110.00 & 114.37 & 117.00 & 116.19 & 114.74 \\
\hline Integrated Nutrient management I $\left(\mathbf{N}_{2}\right)$ & 58.78 & 104.37 & 114.04 & 116.48 & 115.41 & 114.70 \\
\hline Integrated Nutrient Management II $\left(\mathbf{N}_{3}\right)$ & 60.22 & 105.01 & 112.00 & 117.00 & 116.07 & 115.30 \\
\hline S.E(d) \pm & 1.06 & 0.61 & 0.81 & 0.56 & 0.64 & 0.87 \\
\hline CD at $5 \%$ & NS & 1.29 & 1.71 & NS & NS & NS \\
\hline \multicolumn{7}{|l|}{ Moisture regimes } \\
\hline Continuous flooding $\left(\mathrm{M}_{1}\right)$ & 60.19 & 107.46 & 114.33 & 119.11 & 118.33 & 117.04 \\
\hline No standing water $\left(\mathbf{M}_{2}\right)$ & 60.30 & 106.15 & 113.74 & 117.96 & 116.93 & 116.00 \\
\hline $\begin{array}{l}\text { Flooding at tillering, panicle and } \\
\text { flowering stage }\left(\mathbf{M}_{3}\right)\end{array}$ & 58.15 & 105.78 & 112.33 & 113.41 & 112.41 & 111.70 \\
\hline S.E(d) \pm & 1.06 & 0.61 & 0.81 & 0.56 & 0.64 & 0.87 \\
\hline CD at $5 \%$ & NS & 1.29 & 1.71 & 1.19 & 1.35 & 1.84 \\
\hline
\end{tabular}

Table.3 Periodic number of tillers per hill of rice as affected by different nutrient management practices and different levels of moisture

\begin{tabular}{|c|c|c|c|c|c|c|}
\hline Treatments & $\begin{array}{l}20 \\
\text { DAT }\end{array}$ & $\begin{array}{l}40 \\
\text { DAT }\end{array}$ & $\begin{array}{l}\text { 60 } \\
\text { DAT }\end{array}$ & $\begin{array}{l}80 \\
\text { DAT }\end{array}$ & $\begin{array}{l}\text { 100 } \\
\text { DAT }\end{array}$ & $\begin{array}{l}\text { At } \\
\text { harvest }\end{array}$ \\
\hline \multicolumn{7}{|l|}{ Nutrient management practices } \\
\hline Recommended dose of $\mathbf{N}\left(\mathbf{N}_{\mathbf{1}}\right)$ & - & 2.04 & 2.07 & 2.04 & 2.04 & 2.04 \\
\hline Integrated Nutrient management I $\left(\mathrm{N}_{2}\right)$ & - & 2.19 & 2.22 & 2.22 & 2.22 & 2.22 \\
\hline Integrated Nutrient Management II $\left(\mathbf{N}_{3}\right)$ & - & 2.30 & 2.52 & 2.52 & 2.52 & 2.52 \\
\hline S.E $(d) \pm$ & - & 0.11 & 0.11 & 0.10 & 0.10 & 0.10 \\
\hline CD at $5 \%$ & - & 0.23 & 0.24 & 0.21 & 0.21 & 0.21 \\
\hline \multicolumn{7}{|l|}{ Moisture regimes } \\
\hline Continuous flooding $\left(\mathrm{M}_{1}\right)$ & - & 2.11 & 2.19 & 2.15 & 2.15 & 2.15 \\
\hline No standing water $\left(\mathbf{M}_{2}\right)$ & - & 2.11 & 2.22 & 2.22 & 2.22 & 2.22 \\
\hline $\begin{array}{l}\text { Flooding at tillering, panicle and } \\
\text { flowering stage }\left(\mathbf{M}_{3}\right)\end{array}$ & - & 2.30 & 2.41 & 2.41 & 2.41 & 2.41 \\
\hline 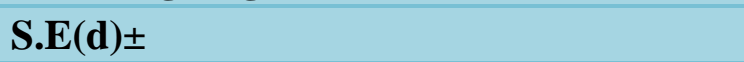 & - & 0.11 & 0.11 & 0.10 & 0.10 & 0.10 \\
\hline CD at $5 \%$ & - & NS & NS & 0.21 & 0.21 & 0.21 \\
\hline
\end{tabular}


Table.4 Periodic leaf number of rice as affected by different nutrient management practices and different levels of moisture

\begin{tabular}{|c|c|c|c|c|c|c|}
\hline Treatments & $\begin{array}{l}20 \\
\text { DAT }\end{array}$ & $\begin{array}{l}40 \\
\text { DAT }\end{array}$ & $\begin{array}{l}\text { 60 } \\
\text { DAT }\end{array}$ & $\begin{array}{l}80 \\
\text { DAT }\end{array}$ & $\begin{array}{l}\text { 100 } \\
\text { DAT }\end{array}$ & $\begin{array}{l}\text { At } \\
\text { harvest }\end{array}$ \\
\hline \multicolumn{7}{|l|}{ Nutrient management practices } \\
\hline Recommended dose of $N\left(N_{1}\right)$ & 6.08 & 10.22 & 9.70 & 8.48 & 7.26 & 7.26 \\
\hline Integrated Nutrient management I $\left(\mathrm{N}_{2}\right)$ & 6.09 & 9.78 & 10.59 & 8.85 & 7.30 & 7.30 \\
\hline Integrated Nutrient Management II ( $\left.\mathrm{N}_{3}\right)$ & 6.24 & 12.15 & 12.69 & 10.04 & 7.93 & 7.93 \\
\hline S.E $(d) \pm$ & 0.13 & 0.39 & 0.38 & 0.52 & 0.40 & 0.40 \\
\hline CD at $5 \%$ & NS & 0.82 & 0.81 & 1.11 & NS & NS \\
\hline \multicolumn{7}{|l|}{ Moisture regimes } \\
\hline Continuous flooding $\left(\mathbf{M}_{1}\right)$ & 6.11 & 10.52 & 10.54 & 8.81 & 7.37 & 7.37 \\
\hline No standing water $\left(\mathbf{M}_{2}\right)$ & 6.15 & 10.59 & 11.00 & 8.78 & 7.11 & 7.11 \\
\hline $\begin{array}{l}\text { Flooding at tillering, panicle and } \\
\text { flowering stage }\left(\mathrm{M}_{3}\right)\end{array}$ & 6.15 & 11.04 & 11.44 & 9.78 & 8.00 & 8.00 \\
\hline $\mathbf{S . E}(\mathbf{d}) \pm$ & 0.13 & 0.39 & 0.38 & 0.52 & 0.40 & 0.40 \\
\hline CD at $5 \%$ & NS & NS & NS & NS & NS & NS \\
\hline
\end{tabular}

Table.5 Yield attributes of rice as affected by different nutrient management practices and different levels of moisture

\begin{tabular}{|c|c|c|c|c|}
\hline Treatments & $\begin{array}{l}\text { Effective } \\
\text { tillers/hill }\end{array}$ & $\begin{array}{l}\text { Panicle } \\
\text { length } \\
(\mathrm{cm})\end{array}$ & $\begin{array}{l}\text { Number of } \\
\text { spikelets/panicle }\end{array}$ & $\begin{array}{l}\text { Test } \\
\text { weight } \\
\text { (g) }\end{array}$ \\
\hline \multicolumn{5}{|l|}{ Nutrient management practices } \\
\hline Recommended dose of $\mathbf{N}\left(\mathbf{N}_{1}\right)$ & 2.04 & 22.27 & 144.20 & 26.18 \\
\hline $\begin{array}{l}\text { Integrated Nutrient management I } \\
\left(\mathbf{N}_{2}\right)\end{array}$ & 2.04 & 21.88 & 148.00 & 26.28 \\
\hline $\begin{array}{l}\text { Integrated Nutrient Management II } \\
\left(\mathbf{N}_{3}\right)\end{array}$ & 2.48 & 22.24 & 147.98 & 28.08 \\
\hline S.E(d) \pm & 0.12 & 0.30 & 3.75 & 0.58 \\
\hline CD at $5 \%$ & 0.26 & NS & NS & 1.24 \\
\hline \multicolumn{5}{|l|}{ Moisture regimes } \\
\hline Continuous flooding $\left(\mathrm{M}_{1}\right)$ & 2.11 & 22.29 & 150.47 & 26.80 \\
\hline No standing water $\left(\mathbf{M}_{2}\right)$ & 2.07 & 22.06 & 149.70 & 26.67 \\
\hline $\begin{array}{l}\text { Flooding at tillering, panicle and } \\
\text { flowering stage }\left(M_{3}\right)\end{array}$ & 2.37 & 22.04 & 140.01 & 27.07 \\
\hline S.E(d) \pm & 0.12 & $\mathbf{0 . 3 0}$ & 3.75 & 0.58 \\
\hline CD at $5 \%$ & 0.26 & NS & 7.95 & NS \\
\hline
\end{tabular}


Table.6 Grain yield, Straw yield and harvest index of rice as affected by different nutrient management practices and different levels of moisture

\begin{tabular}{|c|c|c|c|}
\hline Treatments & $\begin{array}{c}\text { Grain yield } \\
\text { (g/plant) }\end{array}$ & $\begin{array}{c}\text { Straw } \\
\text { yield } \\
\text { (g/plant) }\end{array}$ & $\begin{array}{c}\text { Harvest } \\
\text { Index } \\
(\%)\end{array}$ \\
\hline \multicolumn{4}{|l|}{ Nutrient management practices } \\
\hline Recommended dose of $\mathbf{N}\left(\mathbf{N}_{1}\right)$ & 6.35 & 4.79 & 57.09 \\
\hline Integrated Nutrient management I $\left(\mathbf{N}_{2}\right)$ & 6.32 & 5.47 & 55.99 \\
\hline Integrated Nutrient Management II $\left(\mathbf{N}_{3}\right)$ & 7.55 & 5.87 & 57.57 \\
\hline S.E(d) \pm & 0.19 & 0.24 & 1.60 \\
\hline CD at $5 \%$ & 0.41 & 0.50 & NS \\
\hline \multicolumn{4}{|l|}{ Moisture regimes } \\
\hline Continuous flooding $\left(\mathbf{M}_{1}\right)$ & 6.67 & 5.27 & 56.15 \\
\hline No standing water $\left(\mathbf{M}_{2}\right)$ & 6.52 & 4.95 & 58.87 \\
\hline $\begin{array}{l}\text { Flooding at tillering, panicle and flowering stage } \\
\left(\mathbf{M}_{3}\right)\end{array}$ & 7.01 & 5.90 & 55.63 \\
\hline S.E $(d) \pm$ & 0.19 & 0.24 & 1.60 \\
\hline CD at $5 \%$ & 0.41 & 0.50 & NS \\
\hline
\end{tabular}

Table.7 Water use efficiency of rice as affected by different nutrient management practices and different levels of moisture

\begin{tabular}{|l|l|}
\hline Treatments & Water-use efficiency $(\mathrm{g} / \mathrm{lt})$. \\
\hline Nutrient management practices & 1.28 \\
\hline Recommended dose of $\mathbf{N}\left(\mathbf{N}_{\mathbf{1}}\right)$ & 1.33 \\
\hline Integrated Nutrient management I $\left(\mathbf{N}_{2}\right)$ & 1.67 \\
\hline Integrated Nutrient Management II $\left(\mathbf{N}_{3}\right)$ & 0.07 \\
\hline S.E $(\mathbf{d}) \pm$ & 0.15 \\
\hline CD at 5\% & \\
\hline Moisture regimes & 0.91 \\
\hline Continuous flooding $\left(\mathbf{M}_{1}\right)$ & 1.64 \\
\hline No standing water $\left(\mathbf{M}_{2}\right)$ & 1.74 \\
\hline $\begin{array}{l}\text { Flooding at tillering, panicle and flowering stage } \\
\left(\mathbf{M}_{3}\right)\end{array}$ & 0.07 \\
\hline S.E(d) \pm & 0.15 \\
\hline CD at 5\% & \\
\hline
\end{tabular}

Grain yield, straw yield and harvest index

The effect of different nutrient management practices on both grain and straw yield of rice was significant and significantly higher yield been found for $\mathrm{N}_{3}$ level of nutrient management practices. Integrated nutrient management involving the use of organic 
manure along with inorganic fertilization not only reduces the demand but it was found that the nitrogen use efficiency indices such as agronomic efficiency, physiological efficiency, internal efficiency, recovery efficiency and partial factor productivity were influenced when a part of nitrogen was supplied through organic sources. These activities in turn activate meristematic tissues which remain functional for longer periods resulting in better expression of yield and yield attributes converting more solar energy to productive energy. This result is being supported by the findings of Rahaman and Sinha (2013).

Effect of different moisture levels on both grain and straw yield had also been very significant with $\mathrm{M}_{3}$ treatment level consisting of highest yield. The reason behind this might be the same as for the effective tillers no./hill which is similar with the reports of IRRI, 2009 and Bouman et al., (2007).

There were no significant differences on the effects of both different nutrient management practices and different moisture levels on harvest index of rice.

\section{Water use efficiency}

The effect due to different nutrient management practices on water use efficiency of rice was found to be significant. It was noticed that the maximum water use efficiency was obtained with and was significantly superior to the rest of the treatments.

It may be due to the fact that nitrogen uses efficiency indices such as agronomic efficiency, physiological efficiency etc. were influenced when part of nitrogen was supplied through organic sources. Here, the result is in supported with the findings of Waraich et al., (2011) and Rahaman and Sinha (2013).
The effect due to different levels of moisture on water use efficiency of rice was found to be significant and it was found that $M_{3}$ included with significantly higher water use efficiency which is though statistically at par with $\mathrm{M}_{2}$ level. The probable reason behind this might be that flooding only in certain growth stages requires less water than conventional method of flooding throughout the season, because percolation rate is reduced by the reduction in the hydraulic head of the ponded water. On the other hand meeting moisture demand under recommended submergence at specific growth stages also provide favourable growing and nutrient supply environment resulted in almost equivalent yield of conventional methods. The result shows inconformity with the findings of Shaibu et al., (2014), Lu et al., (2000) and Pandey et al., (2010).

From the above study the following conclusion can be done that among different nutrient management practices, Integrated Nutrient Management II viz. $30 \mathrm{~kg} \mathrm{~N} / \mathrm{ha}$ from Urea $+15 \mathrm{~kg} \mathrm{~N} / \mathrm{ha}$ from FYM $+15 \mathrm{~kg} \mathrm{~N} / \mathrm{ha}$ from Azolla shows better performance in most of the biometric and yield performances and water use efficiency than others. However $\mathrm{N}_{1}$ level was statistically at par with this in some cases like plant height etc.

Now, among different levels of moisture, $\mathrm{M}_{3}$ viz. Maintaining $5 \mathrm{~cm}$ water depth only at tillering, Panicle Initiation (PI) and flowering stage can be recommended as showing better performance than other levels. And $\mathrm{M}_{1}$ and $\mathrm{M}_{2}$ levels were almost having the same performance in most cases.

\section{Acknowledgement}

The first author is thankful to College of Agriculture, Central Agricultural University, Imphal and ICAR Research Complex for $\mathrm{NEH}$ Region, Lamphelpat for providing 
necessary facilities to undertake the M.Sc. (Agronomy) research work.

\section{References}

Acharya, D. and Mondal, S.S. (2010). Effect of integrated nutrient management on the growth, productivity and quality of crops in rice (Oryza sativa) - cabbage (Brassica oleracea) - green gram (Vigna radiata) cropping system. Indian Journal of Agronomy, 55(1): 1-5.

Belder, P., Bouman, B.A.M., Cabangon, R., Guoan, L., Quilang, E.J.P., Yuanhua, L., Spiertz, J.H.J. and Tuong, T.P. (2004). Effect of water-saving irrigation on rice yield and water use in typical lowland conditions in Asia. Agricultural Water Management, 65(3): 193-210.

Bouman, B.A.M., Humphrey, E., Tuong, T.P. and Barker, R. (2007). Rice and water. Advances in Agronomy, 92(4): 187-237.

Dwivedi, B.S., Pandey, A.K., Tiwari, R.K. and Khamparia, N.K. (2012). Performance of integrated nutrient management on yield and uptake of direct seeded rice. Prog. Agric, 12(2): 381-385.

IRRI (2001) Water in rice research: The way forward. IRRI Annual Report, 20002001.17 pp.

IRRI (2009) Rice fact sheet: Saving water: Alternate Wetting Drying (AWD), International Rice Research Institute, Las Banos, August 2009.

Jeyajothi, R. and Durairaj, S. (2015). Influence of integrated nutrient management practices on yield and yield attributes, and economics of transplanted rice (Oryza sativa) in south zone of Tamil Nadu. International Journal for Innovative Research in Science \& Technology, 1(11): 80.

John, P.S., George, M. and Jacob, R.Z. (2001). Nutrient mining in agro-climatic zones of Kerala. Fertilizer News, 46: 45-52 and 55-57.
Keizrul, A. and Azuhan, M. (1998). Water A situation appraisal and possible actions at the community level. Seminar on local communities and the environment II, Environmental Protection Society of Malaysia, Petaling Jaya, Malaysia.

Kumar, S., Singh, R. S., and Kumar, K. 2014. Yield and nutrient uptake of transplanted rice (Oryza sativa) with different moisture regimes and integrated nutrient supply. Current Advances in Agricultural Sciences (An International Journal), 6(1): 64-66.

Lu, J., Ookawa, T. and Hirasawa, T. (2000). The effects of irrigation regimes on the water use, dry matter production and physiological responses of paddy rice. Plant and Soil, 223(1-2): 209-218.

Oo, A.N., Banterng, P., Polthanee, A. and Trelo-Ges, V. (2010). The effect of different fertilizers management strategies on growth and yield of upland black glutinous rice and soil property. Asian Journal of Plant Sciences, 9(7): 414-422.

Pandey, N., Verma, A.K., Anurag and Tripathi, R.S. (2007). Integrated nutrient management in transplanted hybrid rice (Oryza sativa). Journal of Agronomy, 52(1): 40-42.

Pandey, N., Verma, A. K., and Tripathi, R. S. (2010). Response of hybrid rice to scheduling of nitrogen and irrigation during dry season. ORYZA-An International Journal on Rice,47(1), 34-37.

Qin, J., Hu, F., Zhang, B., Wei, Z. and Li, H. (2006). Role of straw mulching in noncontinuously flooded rice cultivation. Agricultural Water Management, 83(3): 252-260.

Rahaman, S. and Sinha, A. C., (2013). Effect of water regimes and organic sources of nutrients for higher productivity and nitrogen use efficiency of summer rice 
(Oryza sativa). African Journal of Agricultural Research, 8(48), 61896195.

Ramaiah, K. and Rao, M.V.B.N. (1953). Rice Breeding and Genetics. ICAR Science Monograph 19.Indian Council of Agricultural Research, New Delhi, India.

Singh, D. and Kumar, A. (2014). Effect of sources of nitrogen on growth, yield and uptake of nutrient in rice. Annals of Plant and Soil Research, 16(3): 192197.

Singha, K. (2013). Growth of Paddy
Production in India's North Eastern Region: A Case of Assam. Anvesak 42, 193-206.

Swaminathan, M.S. (2002). Green revolution is now greed revolution. The Hindu, dt.02.08.2002, pp.5

Waraich, E. A., Ahmad, R., Ashraf, M. Y., Saifullah, and Ahmad, M. (2011). Improving agricultural water use efficiency by nutrient management in crop plants. Acta Agriculturae Scandinavica, Section B-Soil \& Plant Science, 61(4): 291-304.

\section{How to cite this article:}

Barnali Narayan, L. Nabachandra Singh, K. Nandini Devi, S. Jekendra Singh and Gopimohan Singh, N. 2020. Influence of Different Nutrient Management Practices on the Performance of Rice (Oryza sativa L.) Variety CAU R1 under Different Moisture Regimes. Int.J.Curr.Microbiol.App.Sci. 9(09): 2654-2664. doi: https://doi.org/10.20546/ijcmas.2020.909.331 